\title{
Distribusi Fe- dan Al-humus serta C organik Tanah pada Entisol dan Inceptisol di Lahan Kering Jantho, Kabupaten Aceh Besar
}

\author{
(Distribution of Fe-and Al-humus and organic C on Entisol and Inceptisol \\ in Drylands of Jantho, Aceh Besar District) \\ Cut Fajrina ${ }^{1}$, Teti Arabia ${ }^{1}$, Sufardi $^{{ }^{*}}$ \\ ${ }^{1}$ Program Studi Ilmu Tanah, Fakultas Pertanian, Universitas Syiah Kuala
}

\begin{abstract}
Abstrak. Humus merupakan senyawa organik yang sangat penting di dalam tanah karena dapat membentuk kompleks dengan kation logam, sehingga mengurangi toksisitas pada tanaman. Penelitian ini bertujuan untuk mengetahui kandungan dan distribusi Fe- dan Al-humus serta $\mathrm{C}$ organik tanah pada Entisol dan Inceptisol di lahan kering Jantho, Kabupaten Aceh Besar. Sampel tanah diambil pada setiap lapisan horison dari profil tanah ordo Entisol (Typic Udorthents) dari Desa Jalin, Inceptisol (Lithic Dystrudepts) Buket Meusara, dan Inceptisol (Oxic Dystrudepts) dari Desa Cucum, kemudian dibawa ke Laboratorium untuk dianalisis $\mathrm{Fe}$ - dan Al- humus serta $\mathrm{C}$ organik tanah. Fe- dan Al-humus diekstrak dengan larutan 0,1 N Na-pirofosfat (metode van Reeuwijk, 1992) sedangkan Fe dan Al dalam ekstrak Na-pirofosfat diukur dengan AAS. Kandungan C organik ditetapkan dengan metode Wakley dan Black yaitu destruksi dengan asam sulfat dan kalium bikromat dan pengukuran $\mathrm{C}$ dilakukan dengan titrasi $\mathrm{FeSO}_{4}$. Hasil Penelitian menunjukkan bahwa kandungan Fe-humus tanah pada ketiga ordo tanah tergolong sangat rendah $(0,05-0,09 \%)$ sedangkan Alhumus tanah bervariasi dari rendah sampai sedang (2,54 - 6,89\%). Pada Entisol Jalin, distribusi Fe-humus dan Al-humus semakin meningkat dengan kedalaman, sedangkan pada Inceptisol Buket Meusara dan Inceptisol Cucum, Fe-humus cenderung semakin menurun dengan kedalaman, sementara Al-humus sangat bervariasi. Kandungan $\mathrm{C}$ organik tanah di lahan kering Jantho, Aceh Besar pada Entisol dan 0,14 - 0,72\% pada Inceptisol Buket Meusara, dan 0,15 - 1,25\% pada Inceptisol Cucum. Kandungan Fe- dan Al-humus tanah tidak berkorelasi langsung dengan kandungan $\mathrm{C}$ organik.
\end{abstract}

Kata Kunci: C organik, Fe-/Al-humus, lahan kering, Entisol dan Inceptisol

\begin{abstract}
Humus is a very important organic compound in the soil because it can form complexes with metal cations, so as reducing toxicity to plants. This study aimed to determine the content and distribution of Fe- and Al-humus and soil organic C in Entisol and Inceptisol in dry land of Jantho, Aceh Besar District. Soil samples were taken at each layer of the horison from the soil profile of Entisol (Typic Udorthents) order from Jalin Village, Inceptisol (Lithic Dystrudepts) Buket Meusara, and Inceptisol (Oxic Dystrudepts) from Cucum Village, then taken to the Laboratory for $\mathrm{Fe}$ - and Al-humus analysis and soil organic $\mathrm{C}$. Fe- and Al-humus were extracted with $0.1 \mathrm{~N}$ Na-pyrophosphate solution (van Reeuwijk method, 1992) while $\mathrm{Fe}$ and $\mathrm{Al}$ in Napyrophosphate extract were measured by AAS. Organic C content is determined by Wakley and Black method, which is destruction with sulfuric acid and potassium bicarbonate and measurement $\mathrm{C}$ is carried out by titrating $\mathrm{FeSO} 4$. The results showed that the soil Fe-humus content in the three soil orders was classified as very low $(0.05-0.09 \%)$ while Al-humus soil varied from low to moderate $(2.54-6.89 \%)$. In Entisol Interlace, the distribution of Fe-humus and Al-humus increases with depth, whereas in Inceptisol Buket Meusara and Cucum Inceptisol, Fe-humus tends to decrease with depth, while Al-humus varies greatly. Soil organic C content in Jantho dry land, Aceh Besar in Entisol and $0.14-0.72 \%$ in Meusara Bouquet Inceptisol, and $0.15-1.25 \%$ in Cucum Inceptisol. The content of Fe- and Al-humus soil does not correlate directly with organic $\mathrm{C}$ content.
\end{abstract}

Keywords: organic C, Fe-/Al-humus, dryland, Entisol, Inceptisol

\section{PENDAHULUAN}

Provinsi Aceh memiliki lahan kering yang potensial untuk dikembangkan sebagai areal pertanian khususnya untuk usahatani lahan kering. Lahan kering tersebut sebagian telah dimanfaatkan sebagai lahan tegalan, ladang, kebun campuran, sawah tadah hujan, dan padang pengembalaan. Luas areal lahan kering tersebut diperkirakan 278,581 hektar yang terbentuk atas beberapa jenis tanah seperti Litosol, Regosol, Aluvial, Renzina, Andosol, Kambisol, Podsolik, dan Latosol (Badan Penelitian dan Pengembangan Pengembangan 
Pertanian, 2017). Hasil penelitian oleh Sufardi et al. (2017) menemukan ada beberapa ordo tanah yang berkembang di lahan kering Aceh antara lain Entisol, Inceptisol, Ultisol dan Andisol sehingga secara kualitas, lahan kering ini sangat bervariasi. Berdasarkan hasil penelitian di berbagai wilayah, sebagian besar tanah-tanah yang terdapat pada lahan kering adalah tingkat kesuburan tanah yang rendah.

Beberapa permasalahan yang sering ditemukan pada sistem pertanian lahan kering di wilayah tropika basah antara lain $\mathrm{pH}$ tanah rendah, kandungan $\mathrm{C}$ organik rendah, miskin unsur hara, kapasitas tukar kation dan kejenuhan basa rendah, fiksasi fosfat yang tinggi, serta masalah erosi dan ketersediaan air (Sanchez, 2012). Gilman (1984) menyatakan bahwa tanah-tanah yang berada di daerah iklim tropis tersebut digolongkan sebagai tanah dengan sistem muatan variabel dan memiliki liat aktivitas rendah (low activity clay). Liat dengan aktifitas rendah tersebut dapat disebabkan oleh komposisi tanah yang tersusun atas fraksi-fraksi oksida maupun hidroksida Fe dan Al yang berasal dari mineral-mineral yang terdapat pada tanah tersebut (Sposito, 2010).

Jenis mineral yang mendominasi pada tanah-tanah yang ada di lahan kering yaitu kaolinit, haloisit dan oksida-oksida hidroksida dari fraksi Fe, Al dan Si (Sufardi, 1999) dan komposisi mineral-mineral tersebut sangat tergantung pada tingkat perkembangan tanah (Sanchez, 2012). Berdasarkan hal ini, maka komposisi mineral ini berbeda pada setiap ordo tanah. Fraksi Fe, Al dan Si di dalam tanah menjadi tiga bentuk, yaitu bentuk kristalin, amorf dan bentuk kompleks humus (Buurman, 1996). Schulze (2002) menyatakan bahwa bentuk kristalin merupakan bentuk mineral yang telah memiliki susunan kristal yang tetap dan jelas seperti mineral liat tipe 1:1 (kaolinit, haloysit), mineral liat tipe 2:1 (montmorillonit, vermikulit, klorit, dan sejenisnya), sedangkan bentuk amorf adalah bentuk mineral yang belum diketahui struktur kristalografinya yang sering juga disebut dengan kelompok para kritalin sebagaimana yang banyak terdapat pada tanah-tanah yang berkembang dari abu vulkanik (Wada, 1986, Mizota dan van Reeuwijk, 1989). Stevenson (2007) menyatakan bahwa fraksi humus adalah kation-kation logam seperti Fe dan Al yang berikatan senyawa senyawa humus membentuk susunan kimia yang kompleks. Ketiga fraksi terdapat di dalam tanah dapat berikatan dengan senyawa humus, sehingga akan membentuk ikatan kompleks humus (Tan, 2005).

Komposisi fraksi-fraksi $\mathrm{Fe}, \mathrm{Al}$, dan $\mathrm{Si}$ di dalam tanah sangat penting diketahui karena ketiga bentuk fraksi tersebut sangat berhubungan dengan karakteristik kimia tanah dan dinamika hara. Jika fraksi Fe, Al, dan Si kritalin serta frkasi amorf di dalam tanah terdapat dalam jumlah yang tinggi, maka bentuk-bentuk ini dapat menjerap anion-anion hara seperti fosfat, sulfat dan molibdat di dalam tanah (Bolan et al., 2012), sehingga menyebabkan anion-anion ini tidak tersedia bagi tanaman (Mengel dan Kikrby, 2013). Sebaliknya, fraksi humus Fe/Al di dalam tanah terikat dengan senyawa humus sehingga situs penjerap P menjadi berkurang (Sufardi,1999). Bentuk Fe dan Al-humus ini dapat dekstrak dengan larutan pirofosfat (Buurman, 1996). Anam (2016), mengemukakan bahwa kandungan $\mathrm{Al}$ dan $\mathrm{Fe}$ yang diekstrak dengan pirofosfat $\left(\mathrm{Al}_{\mathrm{p}}\right.$ dan $\left.\mathrm{Fe}_{\mathrm{p}}\right)$ sangat dipengaruhi oleh kandungan bahan organik dalam tanah, karena $\mathrm{Al}_{\mathrm{p}}$ dan $\mathrm{Fe}_{\mathrm{p}}$ merupakan bentuk $\mathrm{Al}$ dan Fe yang terikat dengan bahan organik. Lahan kering merupakan lahan yang memiliki berbagai permasalahan kompoleks yang sangat erat kaitannya dengan komposisi fraksi $\mathrm{Fe}$, $\mathrm{Al}$, dan Si serta humus tanah, maka komposisi Fe- dan Al-humus serta $\mathrm{C}$ organik di dalam tanah sangat penting untuk dikaji. Penelitian ini bertujuan untuk mengetahui kandungan $\mathrm{C}$ organik, Fe- dan Al-humus menurut horison dan distribusi ketiga unsur/frkasi tersebut dalam tanah ordo Entisol dan Inceptisol di Jantho, Aceh Besar. 


\section{METODE PENELITIAN}

Penelitian ini menggunakan metode survai deskriptif yaitu melalui observasi lapangan dan analisis laboratorium untuk pengumpulan data. Survai lapangan dilakukan untuk pengamatan profil tanah/identifkasi ordo (subgroup) tanah dan pengambilan sampel tanah untuk analisis di laboratorium. Penelitian ini dilakukan pada dua ordo tanah yang terdapat pada lahan kering di Kecamatan Jantho, Kabupaten Aceh Besar yaitu Entisol dan Inceptisol. Entisol berlokasi di Desa Jalin ( $05^{\circ} 15^{\prime} 55,0^{\prime \prime}$ LU; 95 $35^{\circ}$ '02,6” BT), sedangkan Inceptisol di Desa Buket Meusara (05 17'34,9” LU; 95 36'53,6” BT), dan Desa Cucum

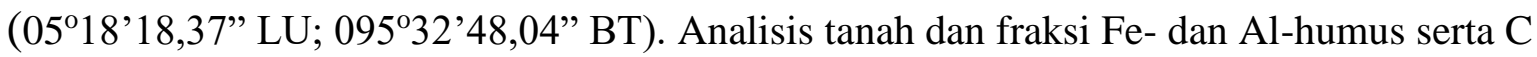
organik dilakukan di Laboratorium Penelitian Tanah dan Tanaman Fakultas Pertanian Universitas Syiah Kuala. Penelitian ini dilaksanakan pada Mei sampai Juli 2018. Alat yang digunakan dalam penelitian ini meliputi peralatan untuk identifikasi ordo tanah di lapangan yaitu bor tanah, $\mathrm{pH}$ digital, cangkul, sekop, abney level, buku warna tanah Munsell, meteran, GPS (global positioning system), camera digital, pisau dan kantong sampel serta larutan kimia $\mathrm{H}_{2} \mathrm{O}_{2} 30 \%$ dan $\mathrm{HCl} 10 \%$. Untuk pengamatan, pengukuran dan analisis laboratorium digunakan beberapa peralatan yaitu timbangan analitik empat digit, botol kocok, pipet digital, pipet volumetrik, $\mathrm{pH}$ meter, shaker, centrifus, homogenizer, dan AAS (atomic absorption spectrophotometer) model 7000S. Bahan kimia yang digunakan meliputi asam sulfat $\left(\mathrm{H}_{2} \mathrm{SO}_{4}\right)$, peroksida $\left(\mathrm{H}_{2} \mathrm{O}_{2}\right)$, asam fosfat $\left(\mathrm{H}_{3} \mathrm{PO}_{4}\right)$, Na-pirofosfat $\left(\mathrm{Na}_{4} \mathrm{P}_{2} \mathrm{O}_{7}\right)$, dan larutan ampul $1000 \mathrm{mg} \mathrm{L}^{-1} \mathrm{Fe}$ dan $1000 \mathrm{mg} \mathrm{L}^{-1} \mathrm{Al}$, serta akuades.

\section{Pengamatan Profil Tanah}

Profil tanah dibuat dengan cara membuka tebing bukit yang telah tersingkap solumnya dan selanjutnya dilakukan pembersihan dinding tebing sehingga tampak profilnya dari lapisan atas hingga sampai terdapat lapisan bahan induk. Profil tanah yang telah dibuka selanjutnya diamati sifat-sifat morfologi yang meliputi batas horison, simbol/nama dan ketebalan tiap lapisan horison, serta sifat-sifat fisika tanah seperti warna tanah, tekstur, struktur, konsistensi, dan ciri khusus seperti fraksi kasar, kongkresi, dan lain-lain yang mungkin ditemukan pada saat pengamatan. Pengamatan sifat-sifat morfologi tanah dan penentuan subgroup (ordo) tanah didasarkan pada panduan pengamatan tanah lapangan (Soil Survey Staff, 2014). Data hasil pengamatan dicatat pada kartu pengamatan dan bersamaan dengan itu juga dilakukan pengumpulan/pengukuran data tentang keadaan lingkungan lahan seperti cuaca, kelerengan, vegetasi dan penggunaan lahan berdasarkan visual, pengukuran topografi menggunakan Abney level dan pengukuran ketinggian tempat dengan GPS. Pengeboran tanah dilakukan pada setiap titik pengamatan untuk memverifikasi morfologi tanah dan ketebalan solumnya. Pengambilan sampel tanah pada setiap profil dilakukan dengan mengambil tanah menurut horison yang telah ditentukan dari masing-masing jenis (subgroup) tanah. Sampel-sampel tersebut dimasukkan kedalam kantong plastik berukuran $1 \mathrm{~kg}$ yang telah diberi kode horison untuk dianalisis di laboratorium.

Untuk keperluan analisis di laboratorium, sampel-sampel tanah diambil pada setiap lapisan horison sesuai dengan morfologi ordo tanah yang dipilih pada saat survai di lapangan yaitu meliputi tiga ordo tanah yaitu Entisol Jalin (Typic Udorthents), Inceptisol Buket Meusara (Lithic Dystrudepts) Buket Meusara, dan Inceptisol Cucum (Oxic Dystrudepts). Banyak sampel tanah untuk setiap horison yang diambil adalah sekitar $1 \mathrm{~kg}$. Sampel tanah yang diambil dari lapangan sebelum dianalisis terlebih dahulu 
dikeringanginkan selama 1 minggu, kemudian ditumbuk dan diayak menggunakan ayakan 100 mesh $(0,5 \mathrm{~mm})$.

\section{Analisis Tanah di Laboratroium}

Sampel-sampel tanah yang telah diambil dari lapangan sebelum dianalisis terlebih dahulu dikering-anginkan selama 1 minggu, kemudian ditumbuk dan diayak menggunakan ayakan 2,0 untuk analisis tekstur tanah dan menggunakan ayakan $0,5 \mathrm{~mm}$ untuk analisis sifat-sifat kimia tanah rutin seperti $\mathrm{pH}, \mathrm{C}$ organik, $\mathrm{N}$ total, $\mathrm{P}$ tersedia, cadangan $\mathrm{P}_{2} \mathrm{O}_{5}$ dan $\mathrm{K}_{2} \mathrm{O}$, kation basa dapat ditukar (Ca-dd, $\mathrm{Mg}$-dd, K-dd, dan Na-dd), kapasitas tukar kation (KTK), kejenuhan basa (KB), aluminium dan hdrogen dapat ditukar (Al-dd dan H-dd) serta daya hantar listrik (DHL). Metode dan prosedur analisis tanah berpedoman pada prosedur yang dikeluarkan oleh Pusat Penelitian Tanah Bogor (2005). Sifat-sifat tanah tersebut dipakai sebagai data pendukung untuk penilaian status kesuburan dan penentuan subgroup tanah.

\section{Penentuan Fe- dan Al-humus serta C organik}

Kandungan Fe- dan Al-humus dianalisis dengan menggunakan metode van Reeuwijk (1992) yaitu dengan ekstraksi tanah menggunakan larutan Na-pirofosfat 0,1 $\mathrm{M}$. Larutan ekstraksi natrium pirofosfat $0,1 \mathrm{M}$ dibuat dengan cara melarutkan 44,6 g Na $\mathrm{P}_{2} \mathrm{O}_{7} .10 \mathrm{H}_{2} \mathrm{O}$ ke dalam 1 liter akuades. Larutan seri standar Fe dan Al dibuat dari standar ampul $1000 \mathrm{mg}$ $\mathrm{L}^{-1} \mathrm{Fe}$ dan $\mathrm{Al}$. Adapun prosedur analisis $\mathrm{Fe}$ - dan Al-humus adalah: Tanah ditimbang sebanyak 0,5 g untuk masing-masing sampel tanah, kemudian dimasukkan ke dalam botol plastik kapaistas $250 \mathrm{ml}$ dan selanjutnya ditambah $50 \mathrm{ml}$ ekstraktan (larutan Na-pirofosfat 0,1 M) menggunakan pipet gondok dan dikocok selama 12 jam dengan mesin pengocok. Setelah pengocokan dipepet $25 \mathrm{~mL}$ suspensi dan dimasukkan ke dalam tabung untuk disentrifus selama 15 menit pada $2500 \mathrm{rpm}$, kemudian disaring dengan kertas saring Whattman 42 dan larutan beningnya disimpan dalam botol gelap. Selanjutnya dilakukan pengenceran $5 \mathrm{x}$ dan 20x untuk pengukuran $\mathrm{Fe}$ dan $\mathrm{Al}$ dengan AAS pada panjang gelombang masing-masing 248,3 $\mathrm{nm}$ dan $309,3 \mathrm{~nm}$. Perhitungan kandungan $\mathrm{Fe}-$ dan Alhumus dinyatakan dalam persen menggunakan rumus berikut:

Keterangan:

$$
\text { Fe- dan Al-humus }(\%)=\frac{(C-B) X D X\left(W-\left(\frac{W}{m c f}\right) \times m c f\right.}{W X 10}
$$

$C \quad=$ Konsentrasi $\mathrm{Fe}$ atau $\mathrm{Al}$ pada sampel $\left(\mathrm{mg} \mathrm{L}^{-1}\right)$

$B \quad=$ Konsentrasi Fe atau Al pada blanko $\left(\mathrm{mg} \mathrm{L}^{-1}\right)$

$D \quad=$ Faktor pengencer

$m c f=$ Faktor koreksi kelembaban

$W \quad=$ Berat sampel $(\mathrm{mg})$

$50=$ volume ekstraktan.

Kandungan $\mathrm{C}$ organik tanah pada setiap lapisan horison dari profil tanah dianalisis dengan menggunakan metode Walkley dan Black. Tanah dioksidasi dengan asam sulfat $\left(\mathrm{H}_{2} \mathrm{SO}_{4}\right)$ pekat dan kalium bikromat $\left(\mathrm{K}_{2} \mathrm{Cr}_{2} \mathrm{O}_{7}\right)$, kemudian dititrasi dengan larutan $\mathrm{FeSO}_{4}$. Hasil perhitungan konsetrasi $\mathrm{C}$ dalam tanah dinyatakan dalam persen. 


\section{HASIL DAN PEMBAHASAN}

\section{A. Deskripsi dan Karakteristik Tanah}

Hasil identifikasi sifat-sifat morfologi dan ciri horison penciri pada setiap profil dari tiga ordo tanah dari lahan kering Jantho, Kabupaten Aceh Besar disajikan pada Tabel 1. Berdasarkan pengamatan profil dan analisis menunjukkan bahwa Entisol Jalin merupakan ordo tanah yang belum berkembang dan hanya tersusun atas horison $\mathrm{A}, \mathrm{AC}$, dan $\mathrm{C}$ dengan ketebalan solum $<50 \mathrm{~cm}$. Tanah ini belum berkembang karena terdapat pada topografi berbukit hingga bergunung dan terbentuk atas batuan endapan yang miskin hara karena tersusun atas mineral campuran berupa gibsit, metaholoysit, dan feldspar. Inceptisol Buket Meusara dan Inceptisol Cucum merupakan dua ordo tanah yang sedang berkembang yang dicirikan dengan horison kambik. Ketebalan solum tanah relatif dalam $(80-110 \mathrm{~cm})$ dan tersusun atas mineral campuran antara feldspar, kalsit, gibsit, dan goethite. Namun dilihat dari komposiis kineral ini, Inceptisol Cucum lebih berkembang daripada Inceptisol Buket Meusara.

Tabel 1. Klasifikasi subgroup tanah menurut Soil Survey Staff (2014) dari tiga ordo tanah di lahan kering Jantho, Kabupaten Aceh Besar

\begin{tabular}{llllll}
\hline Ordo & Subgroup & Tekstur & Susunan horison & Rezim tanah & $\begin{array}{l}\text { Mineral } \\
\text { dominan }\end{array}$ \\
\hline $\begin{array}{l}\text { Entisol } \\
\text { Jalin }\end{array}$ & $\begin{array}{l}\text { Typic } \\
\text { Udorthents }\end{array}$ & Medium & $\mathrm{A}, \mathrm{AC}, \mathrm{C}$ & Udic, IHP & Campuran \\
$\begin{array}{l}\text { Inceptisol } \\
\text { Buket Meusara }\end{array}$ & $\begin{array}{l}\text { Lithic } \\
\text { Dystrudepts }\end{array}$ & Medium & $\mathrm{A}, \mathrm{BA}, \mathrm{Bw}, \mathrm{BC}$ & Udic, IHP & Campuran \\
$\begin{array}{l}\text { Inceptisol } \\
\text { Cucum }\end{array}$ & Oxic & Medium & $\mathrm{Ap}, \mathrm{AB}, \mathrm{BA}, \mathrm{Bk}_{1}, \mathrm{Bk}_{2}$ & Udic, IHP & Campuran \\
\hline IHP = isohyperthermic & & & &
\end{tabular}

IHP $=$ isohyperthermic

Tabel 2 memperlihatkan bahwa secara umum ketiga ordo tanah yang terdapat di lahan kering Jantho Kabupaten Aceh Besar memiliki sifat fisika yang relatif baik pada lapisan atas dan lapisan di bawahnya dengan tekstur sedang, berstruktur gembur hingga agak gembur pada lapisan atas dan berstruktur gumpal hingga massif pada lapisan bawah, serta memiliki konsisten lembab gembur hingga agak teguh. Warna tanah sedikit bervariasi antara ordo tanah walaupun kenampakan matriks tanah cenderung berwarna kuning hingga kecoklatan.

Tabel 2. Sifat-sifat fisika tanah pada setiap lapisan horison pada Entisol dan Inceptisol di lahan kering Jantho, Kabupaten Aceh Besar

\begin{tabular}{|c|c|c|c|c|c|c|c|c|c|}
\hline \multirow{2}{*}{ Ordo } & \multirow{2}{*}{ Horison } & \multirow{2}{*}{$\begin{array}{l}\text { Kedalaman } \\
(\mathrm{cm})\end{array}$} & Pasir & Debu & Liat & \multirow{2}{*}{$\begin{array}{l}\text { Kelas } \\
\text { tekstur }\end{array}$} & \multirow{2}{*}{ Warna } & \multirow{2}{*}{ Struktur } & \multirow{2}{*}{$\begin{array}{c}\text { Konsistensi } \\
\text { (lembab) }\end{array}$} \\
\hline & & & \multicolumn{3}{|c|}{--.--- $(\%)-$} & & & & \\
\hline Entisol & $\mathrm{A}$ & $0-12$ & 14 & 59 & 27 & LD & 7.7 YR 2/2 & Remah & Gembur \\
\hline \multirow[t]{2}{*}{ (Jalin) } & $\mathrm{AC}$ & $12-44$ & 13 & 61 & 26 & LP & 10 YR 2/3 & Gp bersudut & Agak gembur \\
\hline & $\mathrm{C}$ & $>44$ & 13 & 50 & 37 & LD & 7.5 YR 3/4 & Masif & Teguh \\
\hline Inceptisol & $\mathrm{A}$ & $0-20$ & 10 & 49 & 41 & LD & $7.5 \mathrm{YR} 4 / 4$ & Gumpal & Agak gembur \\
\hline \multirow[t]{3}{*}{ (Buket Meusara) } & $\mathrm{BA}$ & $20-54$ & 9 & 65 & 26 & LD & 7.5 YR 4/6 & Gumpal & Agak gembur \\
\hline & Bw & $54-80$ & 6 & 58 & 36 & LD & $5 \mathrm{YR} 4 / 4$ & Butiran & Agak teguh \\
\hline & $\mathrm{BC}$ & $80-106$ & 9 & 65 & 26 & LD & $5 \mathrm{YR} 4 / 8$ & Masif & Teguh \\
\hline Inceptisol & Ap & 0-19 & 29 & 50 & 21 & $\mathrm{~L}$ & 7.5 YR 5/6 & Remah & Gembur \\
\hline \multirow[t]{4}{*}{ (Cucum) } & $\mathrm{AB}$ & $19-42$ & 18 & 57 & 25 & LLi & 10 YR 5/6 & Gumpal & Agak gembur \\
\hline & BA & $42-70$ & 14 & 60 & 25 & LLi & 10 YR 6/6 & Gp bersudut & Agak teguh \\
\hline & $\mathrm{Bk}_{1}$ & $70-110$ & 13 & 54 & 33 & LLi & $10 \mathrm{YR} 7 / 1$ & Gumpal & Agak gembur \\
\hline & $\mathrm{Bk}_{2}$ & $>110$ & 12 & 39 & 49 & $\mathrm{Li}$ & 10 YR 5/1 & Masif & Teguh \\
\hline
\end{tabular}

$\mathrm{LD}=$ lempung berdebu, $\mathrm{LP}=$ lempung berpasir, $\mathrm{Li}=$ liat, $\mathrm{LLi}=$ lempung berliat, $\mathrm{LiD}=$ liat berdebu, $\mathrm{L}=$ lempung 


\section{B. Kandungan Fe-humus, Al-humus, dan C organik}

Hasil analisis laboratorium terhadap kandungan $\mathrm{Fe}$ - dan Al-humus tanah yang diekstrak dengan larutan Na-pirofosfat 0,1 $M$, serta kandungan $\mathrm{C}$ organik (metode Walkley and Black) pada setiap ordo tanah dapat disajikan dalam Tabel 3.

Tabel 3. Kandungan Fe- dan Al-humus serta C organik tanah pada Entisol dan Inceptisol di lahan kering Jantho, Kabupaten Aceh Besar

\begin{tabular}{lccccc}
\hline \multicolumn{1}{c}{ Ordo } & $\begin{array}{c}\text { Simbol } \\
\text { horison }\end{array}$ & $\begin{array}{c}\text { Kedalaman } \\
(\mathrm{cm})\end{array}$ & $\begin{array}{c}\text { Fe-humus } \\
(\%)\end{array}$ & $\begin{array}{c}\text { Al-humus } \\
(\%)\end{array}$ & $\begin{array}{c}\text { C organik } \\
(\%)\end{array}$ \\
\hline Entisol & $\mathrm{A}$ & $0-12$ & 0,08 & 3,02 & 1,53 \\
(Jalin) & $\mathrm{AC}$ & $12-44$ & 0,09 & 3,99 & 0,21 \\
& $\mathrm{C}$ & $>44$ & 0,08 & 4,15 & 0,14 \\
\hline Inceptisol & $\mathrm{A}$ & $0-20$ & 0,06 & 2,54 & 0,72 \\
(Buket Meusara) & $\mathrm{BA}$ & $20-54$ & 0,05 & 3,50 & 0,14 \\
& $\mathrm{Bw}$ & $54-80$ & 0,06 & 3,50 & 0,36 \\
& $\mathrm{BC}$ & $80-106$ & 0,06 & 2,86 & 0,29 \\
\hline Inceptisol & $\mathrm{Ap}$ & $0-19$ & 0,05 & 6,40 & 1,25 \\
(Cucum) & $\mathrm{AB}$ & $19-42$ & 0,06 & 5,28 & 0,44 \\
& $\mathrm{BA}$ & $42-70$ & 0,08 & 6,40 & 0,36 \\
& $\mathrm{Bk}{ }_{1}$ & $70-110$ & 0,08 & 4,95 & 0,15 \\
& $\mathrm{Bk}_{2}$ & $>110$ & 0,07 & 6,89 & 0,18 \\
\hline
\end{tabular}

Tabel 3 memperlihatkan bahwa kandungan Fe-humus yang terdapat pada tiga lapisan horison Entisol Jalin termasuk ke dalam kategori sangat rendah $(<0,1 \%)$ yaitu berkisar dari 0,08-0,09\%. Walaupun jika dilihat dari kandungan $\mathrm{C}$ organik yang menunjukkan lapisan atas lebih tinggi daripada lapisan bawah tetapi relatif tidak berpengaruh terhadap kandungan Fe-humus. Hal ini diduga karena kandungan bahan organik tanah tergolong rendah sehingga komposisi senyawa humus belum mampu membentuk ikatan dengan logam Fe membentuk kelasi (Tan, 2005). Hasil penelitian Kurniati (2016) pada tanah Regosol yang juga termasuk ordo Entisol, ternyata $\mathrm{Fe}$ yang diekstrak dengan pirofosfat (Fe-humus) jumlahnya pada horison $\mathrm{A}$ sebesar $0,55 \%$ dan horison $\mathrm{C}$ sebesar $0,61 \%$. Hal ini menunjukkan bahwa kandungan Fe-humus tanah dapat berbeda antar jenis tanah walaupun dalam satu ordo tanah.

Selanjutnya, pada Inceptisol Buket Meusara, Fe-humus berkisar dari 0,05-0,06\% (sangat rendah). Kandungan Fe-humus pada horison A sebesar 0,06\%, kemudian menurun menjadi $0,05 \%$ pada horison BA dan meningkat kembali pada horison Bw dan BC menjadi 0,06\%. Pada Inceptisol Cucum, Fe-humus berkisar dari 0,05-0,08\% (sangat rendah). Kandungan Fe-humus pada horison Ap sebesar 0,05\%, kemudian meningkat pada horison BA hingga horison Bk1 menjadi 0,08\% dan setelah itu menurun kembali pada horison Bk2 menjadi $0,07 \%$. Hal ini menunjukkan bahwa ada sedikit variasi kandungan $\mathrm{Fe}$-humus tanah pada setiap lapisan horison. Hasil penelitian serupa mengenai $\mathrm{Fe}$-humus $\left(\mathrm{Fe}_{\mathrm{p}}\right) \mathrm{di}$ lahan kering oleh Arabia (2009), menunjukkan bahwa kandungan $\mathrm{Fe}_{\mathrm{p}}$ pada Latosol Coklat (Inceptisol) tergolong rendah yaitu $0,82 \%$ pada horison Ap dan 0,65\% pada horison Bw1, sedangkan pada horison $\mathrm{Bw} 2$ dan $\mathrm{Bw} 3$ kandungan $\mathrm{Fe}_{\mathrm{p}}$ tidak terukur.

Tabel 3 juga memperlihatkan bahwa kandungan Al-humus pada Entisol Jalin pada horison A sebesar 3,02\%, kemudian terjadi kenaikan pada horison AC menjadi 3,99\% dan 
semakin meningkat pada horison C menjadi 4,15\%. Kandungan Al-humus ini ternyata lebih tinggi daripada kandungan Fe-humus dan hasil ini berbeda dengan hasil penelitian Kurniati (2016) pada lahan kering Entisol (Regosol) yang mendapatkan bahwa kandungan $\mathrm{Al}$ yang diekstrak dengan Na-pirofosfat pada horison A yaitu $0,05 \%$ dan horison $\mathrm{C}$ yaitu $0,08 \%$. Perbedaan ini berkaitan erat dengan proses-proses yang terjadi di dalam tanah yang tidak hanya tergantung pada kandungan $\mathrm{C}$ organik tetapi juga proses lainnya seperti pencucian, kandungan liat, dan jenis bahan induk tanah. Entisol Jalin yang terbentuk dari bahan induk batuan endapan memiliki komposisi liat yang lebih tinggi jika dibandingkan dengan Entisol yang terbentuk dari pasir, sehingga proses pembentukan fraksi Fe/Al humus ini berbeda. Menurut Kurniati (2016) rendahnya Al yang diekstrak dengan Napirofosfat karena unsur Al tersebut bentuknya berikatan dengan bahan organik sehingga ketersediaan di dalam tanah sedikit jumlahnya.

Kandungan Al-humus tanah pada Inceptisol Buket Meusara berkisar dari 2,542,86\%. Pada horison A kandungan Al-humus sebesar 2,54\% kemudian pada horison BA dan Bw terjadi kenaikan menjadi 3,50\% dan selanjutnya terjadi penurunan pada horison BC dari 3,50\% menjadi 2,54\%. Pada Inceptisol Cucum kandungan Al-humus berkisar dari 4,95-6,89\% yaitu 6,40\% pada horison Ap kemudian menurun menjadi 5,28\% pada horison $\mathrm{AB}$, dan meningkat kembali pada horison BA menjadi 6,40\%. Setelah itu, kandungan Alhumus menurun kembali pada horison Bk1 menjadi 4,95\% yang selanjutnya meningkat kembali menjadi $6,89 \%$ pada horison Bk2. Hal ini menunjukkan bahwa secara umum kandungan Al-humus tanah pada kedua ordo Inceptisol Jantho ini sangat bervariasi dari rendah hingga sedang pada antar lapisan horison. Variasi ini menunjukkan bahwa proses pembentukan horison tanah turut mempengaruhi transformasi mineral yang menyebabkan terjadinya perbedaan dalam komposisi senyawa Fe-humus dan Al-humus tanah. Hasil penelitian serupa oleh Arabia (2009) pada lahan kering menunjukkan bahwa kandungan Al yang diekstrak oleh larutan Na-pirofosfat pada Inceptisol (Latosol Coklat) tergolong ke dalam kriteria rendah yaitu $0,96 \%$ pada horison Ap dan $0,94 \%$ pada horison Bw1, sedangkan pada horison $\mathrm{Bw} 2$ dan $\mathrm{Bw} 3$ kandungan $\mathrm{Al}_{\mathrm{p}}$ tidak terukur. Hal ini disebabkan karena unsur Al berada dalam bentuk terikat dengan bahan organik lebih sedikit sehingga Alp tanah tersebut kandungannya rendah. Selain itu, perbedaan kandungan Al-humus antar ordo tanah juga sangat erat kaitannya dengan proses genesis tanah yang juga bergantung pada komposisi bahan induk (Mulyanto et al., 2011). Hasil penelitian yang telah dilakukan oleh Fajrina et al. (2018), menunjukkan bahwa kandungan Al-humus tanah juga cukup bervariasi antar beberapa ordo tanah (Andisols, Ultisols, Oxisols, dan Mollisols) yang terdapat pada lahan kering di Aceh Besar. Hasil penelitian tersebut menyatakan bahwa kandungan Al-humus tanah bervariasi dari rendah hingga sedang.

Tabel 3 memperlihatkan bahwa kandungan $\mathrm{C}$ organik pada Entisol Jalin berkisar dari 0,14-1,53\% dan termasuk dalam kriteria sangat rendah sampai rendah. Pada horison A, C organik tergolong rendah dengan kandungan 1,53\% dan semakin menurun pada horison AC menjadi $0,21 \%$ sampai horison $\mathrm{C}$ menjadi $0,14 \%$. Beberapa penelitian yang telah dilakukan pada Entisol, ternyata kandungan $\mathrm{C}$ organik sangat bervariasi tergantung dari jenis tanah walaupun dalam satu ordo Entisol (Helmi et al,. 2016, Martunis et al., 2016 dan Sufardi et al., 2017). Kandungan C organik pada Inceptisol Buket Meusara berkisar dari 0,14-0,72\% dan termasuk dalam kriteria rendah. Pada horison A, kandungan $\mathrm{C}$ organik sebesar $0,72 \%$ kemudian menurun pada horison BA menjadi $0,14 \%$ dan meningkat kembali pada horison $\mathrm{Bw}$ menjadi $0,36 \%$, selanjutnya menurun menjadi $0,29 \%$ pada horison BC. Pada Inceptisol Cucum, kandungan C organik tanah berkisar dari 0,15-1,25\% dan termasuk dalam kriteria sangat rendah sampai rendah. Horison yang termasuk dalam kategori sangat rendah yaitu $\mathrm{AB}, \mathrm{BA}, \mathrm{Bk} 1$ dan Bk2 dengan kandungan $\mathrm{C}$ organik masing- 
masing yaitu $0,44 \% ; 0,36 \% ; 0,15 \%$ dan $0,18 \%$, sedangkan pada horison Ap termasuk dalam kategori rendah dengan kandungan $\mathrm{C}$ organik sebesar 1,25\%. Pada horison Ap hingga horison $\mathrm{Bk} 1$ terjadi penurunan kandungan $\mathrm{C}$ organik seiring dengan bertambahnya kedalaman tanah. Berdasarkan data tersebut dapat dinyatakan bahwa kandungan $\mathrm{C}$ organik pada Inceptisol Jantho, Kabupaten Aceh Besar bervariasi antar jenis tanah dan antar horison. Pada horison atas mengandung $\mathrm{C}$ organik yang relatif lebih tinggi daripada pada lapisan di bawahnya. Hal ini disebabkan karena biomassa organik tanah lebih banyak terakumulasi pada lapisan atas karena bahan ini umumnya berasal dari vegetasi yang ada di permukaan tanah (Stevenson, 2007).

Hasil penelitian di daerah Aceh Besar oleh Sufardi et al. (2017) menunjukkan bahwa kandungan $\mathrm{C}$ organik pada kedalaman $20-40 \mathrm{~cm}$ lebih rendah dibandingkan pada kedalaman 0 - $20 \mathrm{~cm}$. Kandungan $\mathrm{C}$ organik di hampir semua area lahan kering Aceh besar berada di bawah $2 \%$ dan termasuk ke dalam kategori rendah.

\section{Distribusi Fe- dan Al-humus, serta C organik}

Distribusi Fe- dan Al-humus serta $\mathrm{C}$ organik menurut kedalaman tanah pada Entisol Jalin Kecamatan Jantho Kabupaten Aceh Besar dapat dilihat pada Gambar 1. Dari gambar terlihat bahwa distribusi atau pola perubahan komposisi $\mathrm{Fe}$ - dan Al-humus menurut kedalaman tanah ternyata tidak searah dengan pola distribusi perubahan kandungan $\mathrm{C}$ organik. Secara umum kandungan Fe-humus pada Entisol lebih rendah daripada kandungan Al-humus, tetapi pola distribusi kedua kation tersebut menurut kedalaman hampir sama yaitu cenderung meningkat dengan bertambahnya kedalaman tanah hingga lapisan $\mathrm{C}$, walapun peningkatannya kandungan Al-humus lebih nyata daripada kandungan Fe-humus. Sebaliknya, kandungan $\mathrm{C}$ organik justru semakin menurun dengan bertambahnya kedalaman tanah. Hal ini merupakan fenomena yang umum terjadi pada kebanyakan tanah yang cenderung $\mathrm{C}$ bahan organik tanahnya terkonsentrasi pada lapisan atas. Dari dua fakta ini menunjukkan bahwa perubahan komposisi fraksi $\mathrm{Fe}$ - dan Al-humus di dalam profil tanah tidak ternyata tidak berkorelasi langsung $(r=0,06-0,15)$ dengan kandungan $\mathrm{C}$ organik tanah. Tidak ada korelasi ini diduga karena fraksi humus yang terdapat di dalam tanah (Entisol Jalin) sangat rendah yang dibuktikan dari rendahnya kandungan bahan organik tanah, sehingga senyawa humus ini tidak banyak berkonstribusi dalam membentuk kelasi dengan kation logam Fe dan/atau Al (Tan, 2005, Stevenson, 2007, Sposito, 2010). Hasil penelitian ini juga sesuai dengan hasil penelitian Kurniati (2016) pada Entisol yang mendapatkan bahwa Fe-humus dan Al-humus meningkat dengan bertambahnya kedalaman tanah, sedangkan kandungan $\mathrm{C}$ organik semakin menurun dan tidak berkaitan langsung dengan kandungan $\mathrm{C}$ organik tanah. Hasil senada juga dilaporkan oleh Fajrina et al. (2018) yang juga mendapatkan bahwa kandungan Fe- dan Al-humus tanah pada lahan kering di Aceh Besar tidak berkorelasi positif dengan kandungan $\mathrm{C}$ organik tanah. 

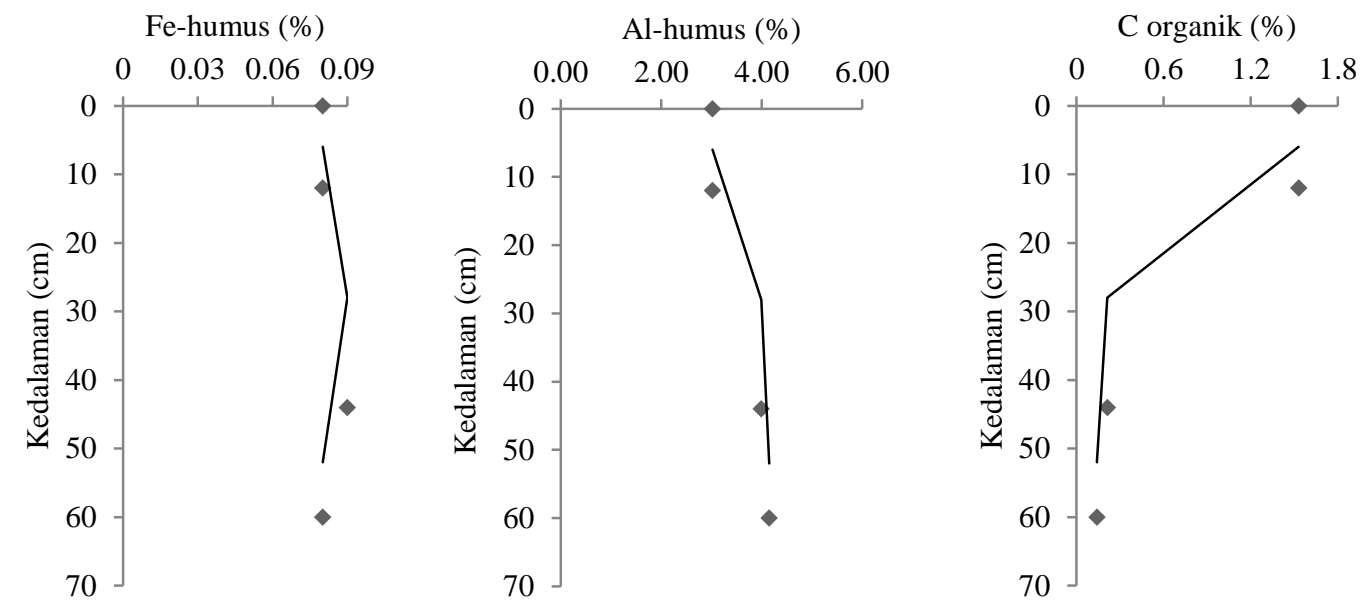

Gambar 1. Distribusi Fe- dan Al-humus, serta C organik pada Entisol Jalin, Jantho Kabupaten Aceh Besar
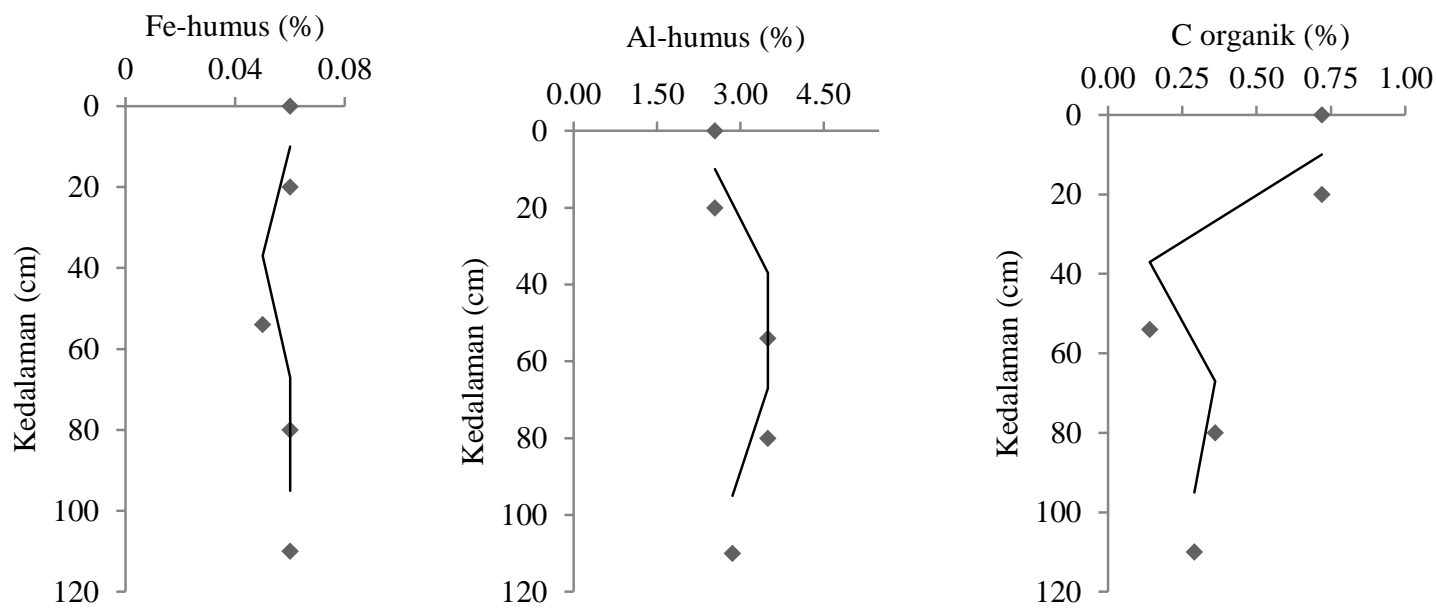

Gambar 2. Distribusi Fe- dan Al-humus, serta C organik pada Inceptisol Buket Meusara, Jantho Kabupaten Aceh Besar
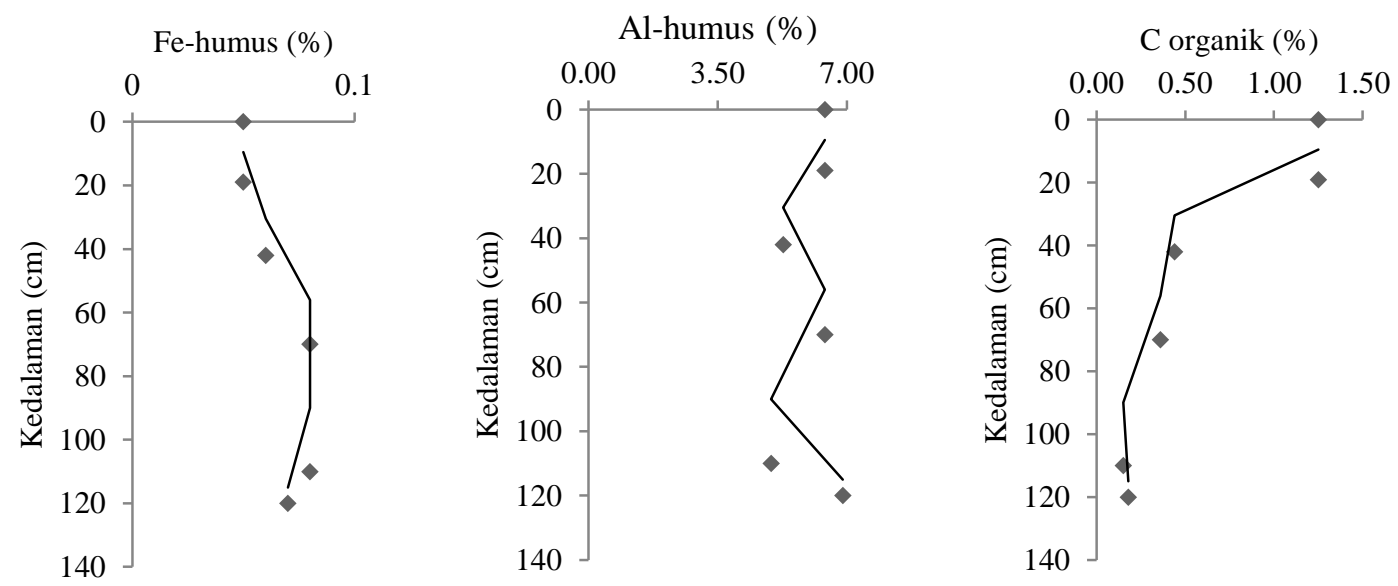

Gambar 3. Distribusi Fe- dan Al-humus, serta C organik pada Inceptisol Cucum, Jantho Kabupaten Aceh Besar 
Pada Inceptisol Buket Meusara kandungan Fe- dan Al-humus, serta C organik tanah juga berbeda pola distribusinya menurut kedalaman. Gambar 2 menunjukkan bahwa perubahan kandungan Fe-humus cenderung tidak berbeda menurut kedalaman tanah, sedangkan Al-humus lebih variatif. Pola distribusi Al-humus tidak konsisten dengan bertambahnya kedalaman. Kandungan Al-humus mengalami peningkatan hingga kedalaman $40 \mathrm{~cm}$, dan setelah itu relatif tidak mengalami perubahan hingga kedalaman 80 $\mathrm{cm}$, namun setelah itu Al-humus menurun kembali sampai lapisan bahan induk. Sementara itu, kandungan $\mathrm{C}$ organik secara tajam menurun dengan bertambahnya kedalaman hingga $40 \mathrm{~cm}$, dan kemudian sedikit meningkat kembali hingga kedalaman $80 \mathrm{~cm}$, namun setelah itu menurun kembali walaupun kandungannya masih jauh lebih rendah jika dibandingkan dengan pada lapisan atas. Fakta ini menunjukkan bahwa pola perubahan kandungan $\mathrm{Fe}$ humus dan Al-humus pada Inceptisol Buket Meusara juga tidak konsisten dengan perubahan kandungan $\mathrm{C}$ organik tanah.

Selanjutnya Gambar 3 memperlihatkan bahwa pola distribusi dan perubahan kandungan Fe-humus dan Al-humus tanah pada Inceptisol Cucum juga berbeda dengan pola perubahan $\mathrm{C}$ organik. Jika dibandingkan dengan pola Fe-humus pada Inceptisol Buket Meusara, maka pola perubahan Fe-humus ini relatif tidak jauh berbeda. Fe-humus tanah sedikit mengalami peningkatan dengan meningkatnya kedalaman tanah, sedangkan Alhumus cenderung berfluktuasi di dalam profil tanah. Pola perubahan kndungan $\mathrm{C}$ organik pada Inceptisol Cucum relatif sama dengan pola distribusi pada Inceptisol Buket Meusara yaitu cenderung mengalami penurunan dengan semakin bertambahnya kedalaman hingga mencapai lapisan bahan induk tanah. Berdasarkan pola distribusi yang disajikan pada Gambar 2 dan Gambar 3, maka dapat dikemukakan bahwa perubahan kandungan $\mathrm{Fe}$ - dan Al-humus tanah tidak selalu mengikuti pola perubahan $\mathrm{C}$ organik. Hal ini terjadi karena kandungan bahan organik yang terdapat pada kedua Inceptisol ini sangat rendah sehingga belum banyak berperan dalam pembentukan kompleks Fe/Al-humus di dalam tanah (Bohn et al. 2010. Selain itu, kandungan $\mathrm{C}$ organik tanah yang tinggi belum menjamin terhadap proses humifikasi yang menghasilkan senyawa humus kompleks (Stevenson, 2007), sehingga parameter untuk melihat korelasi antara bentuk Fe- dan Al-humus tanah dengan bahan organik perlu dilihat dari komposisi dan kualitas humus tanah yang antara lain dengan melihat kandungan asam humat (AH) dan asam fulfat (AF) serta rasio kedua.

Huang dan Schnitzer (1989) menyatakan bahwa di dalam tanah senyawa humus dapat mengikat kation-kation logam seperti Fe, Al, Mn, membentuk senyawa kompleks sehingga kelarutan logam akan berkurang. Pengikatan humus dengan logam ini dapat terjadi karena senyawa humus memiliki situs aktif yang dapat bersenyawa dengan kationkation yang terdapat di dalam tanah melalui proses yang dikenal kelasi (Tan, 2005). Sanchez (2012) menyatakan bahwa salah satu kendala pada kebanyakan lahan kering masam di kawasan iklim tropika basah adalah tingginya kelarutan $\mathrm{Al}$, Mn, dan $\mathrm{Mn}$ sehingga sering menimbulkan keracunan pada tanaman. Keracunan Al dan Fe, serta Mn sering ditemukan pada tanaman budidaya yang tidak toleran (Sanchez dan Salinas, 1982, Fageria et al., 2011, Mengel dan Kirkby, 2013). Dengan rendahnya kandungan Fe-/Alhumus tanah pada ordo Entisol dan Inceptisol di lahan kering Jantho Kabupaten Aceh Besar, maka bentuk Al dan Fe yang terkandung dalam mineral tanah berpotensi menjadi bentuk larut yang membahayakan tanaman, namun hal ini masih perlu dikaji lebih lanjut. Bohn et al. (2010) menyatakan bahwa kelarutan $\mathrm{Al}$ dan $\mathrm{Fe}$ di dalam tanah selain tergantung kepada jenis dan komposisi mineral juga dipengaruhi oleh reaksi tanah $(\mathrm{pH})$ dan keberadaan kation-kation basa sebagai pengimbangnya (counterions). 


\section{Fe- dan Al-humus vs Kesuburan Tanah}

Tabel 4 memperlihatkan bahwa hasil penilaian terhadap kesuburan tanah pada tiga ordo tanah di lahan kering Jantho Kabupaten Aceh Besar menggunakan lima indikator kesuburan tanah, yaitu $\mathrm{C}$ organik, kapasitas tukar kation, kejenuhan basa dan cadangan $\mathrm{P}$ dan $\mathrm{K}\left(\mathrm{P}_{2} \mathrm{O}_{5}\right.$ dan $\mathrm{K}_{2} \mathrm{O}$ ) menunjukkan bahwa Entisl Jalin dan Inceptisol Buket Meusara berstatus kesuburan sedang sementara Inceptisol Cucum termasuk ke dalam status kesuburan rendah. Status kesuburan tanah yang rendah pada Inceptisol Cucum disebabkan ada tiga parameter kimia tanah yang rendah yaitu $\mathrm{C}$ organik, kejenuhan basa, dan cadangan $\mathrm{K}_{2} \mathrm{O}$ tanah.

Tabel 4. Evaluasi status kesuburan tanah pada Entisol dan Inceptisol di lahan kering Jantho, Kabupaten Aceh Besar

\begin{tabular}{|c|c|c|c|c|c|c|c|}
\hline Ordo & Subgroup & $\begin{array}{c}\text { C Organik } \\
(\%)\end{array}$ & $\begin{array}{c}\begin{array}{c}\mathrm{KTK} \\
\left(\mathrm{cmol} \mathrm{kg}{ }^{-1}\right)\end{array} \\
\end{array}$ & $\begin{array}{l}\mathrm{KB} \\
(\%)\end{array}$ & $\begin{array}{c}\begin{array}{c}\mathrm{P}_{2} \mathrm{O}_{5} \\
(\mathrm{mg} / 100 \mathrm{~g})\end{array} \\
\end{array}$ & $\begin{array}{c}\mathrm{K}_{2} \mathrm{O} \\
(\mathrm{mg} / 100 \mathrm{~g}) \\
\end{array}$ & $\begin{array}{c}\text { Status } \\
\text { Kesuburan } \\
\end{array}$ \\
\hline Entisol Jalin & $\begin{array}{l}\text { Typic } \\
\text { Udorthents }\end{array}$ & $1,75(\mathrm{R})$ & $34,4(\mathrm{~T})$ & $19,3(\mathrm{R})$ & $202(\mathrm{~T})$ & $83(\mathrm{~T})$ & Sedang \\
\hline $\begin{array}{l}\text { Inceptisol } \\
\text { Buket Meusara }\end{array}$ & $\begin{array}{l}\text { Lithic } \\
\text { Dystrudepts }\end{array}$ & $0,72(\mathrm{R})$ & $35,2(\mathrm{~T})$ & $18,6(\mathrm{R})$ & $727(\mathrm{~T})$ & $47(\mathrm{~T})$ & Sedang \\
\hline $\begin{array}{l}\text { Inceptisol } \\
\text { Cucum }\end{array}$ & $\begin{array}{l}\text { Oxic } \\
\text { Dystrudepts }\end{array}$ & $1,25(\mathrm{R})$ & 20,8 (S) & $18,8(\mathrm{R})$ & $77(\mathrm{~T})$ & $3(\mathrm{R})$ & Rendah \\
\hline
\end{tabular}

$\mathrm{R} / \mathrm{S} / \mathrm{T}=$ rendah/sedang/tinggi

Dari Tabel 4 juga dapat dilihat bahwa salah satu faktor yang turut mempengaruhi rendahnya kesuburan pada hamper semua tanah yang diteliti adalah kandungan $\mathrm{C}$ organik yang rendah. Berdasarkan hal ini, maka jumlah bahan organik dan distribusinya di dalam tanah sangat penting untuk mempertahankan kualitas tanah (Havlin et al., 2010, Sufardi, 2012). Komposisi mineral tanah dan kandungan berbagai fraksi Fe, Al, dan Si di dalam tanah juga turut mempengaruhi kualitas dan kesuburan suatu tanah walaupun status kesuburan tanah masih dinilai dari beberapa variabel kimia tanah. Kualitas dan sifat kesuburan secara tidak langsung berhubungan dengan bahan induk tanah (Sufardi et al., 2018). Di kawasan iklim tropika basah, pencucian basa di dalam tanah umumnya telah berlangsung lama bersamaan proses pelapukan dan pembentukan tanah (Sanchez, 2012), sehingga pola perubahan pada komposisi mineral juga ikut mengalami perubahan (Bohn et al., 2010). Proses pencucian basa ini menghasilkan tanah-tanah yang miskin hara yang didominasi oleh fraksi Si, Al, dan Fe oksida (Sposito, 2010) dan umumnya menghasilkan tanah yang kurang subur yang memiliki banyak kendala (Sanchez, 2012).

\section{SIMPULAN DAN SARAN}

Kandungan Fe-humus tanah pada ketiga ordo tanah tergolong sangat rendah $(0,05-$ 0,09\%) sedangkan Al-humus tanah bervariasi dari rendah sampai sedang (2,54-6,89\%). Pada Entisol Jalin, distribusi Fe-humus dan Al-humus semakin meningkat dengan kedalaman, sedangkan pada Inceptisol Buket Meusara dan Inceptisol Cucum, Fe-humus cenderung semakin menurun dengan kedalaman, sementara Al-humus sangat bervariasi. Kandungan $\mathrm{C}$ organik tanah di lahan kering Jantho, Aceh Besar pada Entisol dan 0,140,72\% pada Inceptisol Buket Meusara, dan 0,15-1,25\% pada Inceptisol Cucum. 
Distribusi dan perubahan kandungan Fe-humus, Al-humus dan $\mathrm{C}$ organik menurut kedalaman tanah pada ordo Entisol dan Inceptisol dari lahan kering Jantho membentuk pola yang berbeda. Distribusi Fe-humus relatif tidak berbeda dengan kedalaman, sedangkan Al-humus di dalam horison dan kedalaman tanah cenderung tidak konsisten (berfluktuatif) dan pola perubahan Fe-humus dan Al-humus. Kandungan C organik tanah menurun dengan bertambahnya kedalaman, tetapi tidak selalu berkorelasi langsung dengan kandungan $\mathrm{C}$ organik. Aplikasi bahan organik tanah perlu dianjurkan pada ketiga ordo tanah tersebut karena selain dapat meningkatkan kualitas tanah.

\section{DAFTAR PUSTAKA}

Anam, K. 2016. Karakteristik tanah Spodosol di Kalimantan Timur. Skripsi. Program Studi Manajemen Sumberdaya Lahan. Fakultas Pertanian Intstitut Pertanian Bogor, Bogor.

Arabia, T. 1991. Sifat-sifat muatan tanah masam lahan kering di Daerah Sumatra Barat dan Jawa Barat. Tesis. Program Pascasarjana Institut Pertanian Bogor, Bogor.

Arabia, T. 2009. Karakteristik tanah sawah pada toposekuen berbahan induk volkanik di Daerah Bogor - Jakarta. Disertasi. Program Pascasarjana Institut Pertanian Bogor, Bogor.

Badan Penelitian dan Pengembangan Pertanian. 2017. Atlas Peta Tanah Semidetail Skala 1: 50.000 Kabupaten Aceh Besar. ISBN : 978-602-436-598-1

Bohn H.L., McNeal B.L. \&O'Connor G.A. 2010. Soil Chemistry. John Wiley \& Sons. New York.

Bolan, N.S., Kunhikrishnan, A. Choppala, G.K. Thangarajan, R. and J.W. Chung. 2012. Stabilization of carbon in composts and biochars in relation to carbon sequestration and soil fertility. Science of the Total Environment, 424, pp.264-270.

Buurman, T., B.V. Lagen dan E.J. Velthorst. 1996. Manual for Soil and Water Analysis. Backhuys. Netherlands.

Fajrina, C., Sufardi, T. Arabia, dan Khairullah. 2018. Karbon organik, kompleks humus besi dan aluminium pada empat ordo tanah di lahan kering Kabupaten Aceh Besar, Indonesia. Dalam Y. Aisyah, Jauharlina, Sugianto dan D. Yunita. Penguatan Peran Perguruan Tinggi Pertanian dalam Akselerasi Inovasi dan Teknologi untuk Mewujudkan Kedaulatan Pangan Berbasis Sumberdaya dan Kearifan Lokal. Banda Aceh.

Fageria N. K. Moreira A. \& Coelho A. M. 2011. Yield and Yield Components of Upland Rice as Influenced by Nitrogen Sourses. Journal of Plant Nutrition. 34:361-370.

Gilman, G.P. 1984. Using Variable Charge Characteristics to Understand the Exchangeable Cation Status of Oxic Soils. Austr. J. Soil Res. 22:71-80

Havlin J.L. Tisdale S.L. Nelson W.L. and Beaton J.D. 2010. Soil fertility and fertilizers. $8^{\text {th }}$. Ed. Kindle Edition. John Wiley and Sons, New York.

Helmi H. Basri H. and Sufardi S. 2016. Analysis of Soil Quality as Hydrological Disaster Mitigation Effort in Krueng Jreue Sub-Watershed, Great Aceh. Aceh International Journal of Science and Technology, 6(2), pp.75-85.

Huang, P.M. dan M. Schnitzer. 1989. Interactions of Soil Minerals with Natural Organics and Microbes, SSSA Special Publication 17.

Kurniati. 2016. Pedogenesis pada beberapa jenis tanah yang disawahkan di Bogor. Tessis. Program Pascasarjana Institut Pertanian Bogor, Bogor. 
Martunis, L., Sufardi, dan Muyassir. 2016. Analisis indeks kualitas tanah di lahan kering Kabupaten Aceh Besar, J. Budidaya Pertanian. Vol. 12 (1) : 34-40

Mengel, K. dan Kikrby, E. 2013. Principles of Palnt Nutrition. Intern. Potash Inst. Swizerland.

Mizota, C dan L.P. Van Reeuwijk. 1989. Clay Mineralogy and Chemistry of Soil Formed in Volcanic Material in Diverse Region. ISRIC, Wageningen Netherlands.

Mulyanto, D., P.S. Subroto dan H. Lukito. 2011. Genesis pedon yang berkembang di atas batuan karbonat Wonosari Gunung Kidul. Forum Georafi. Vol 25 (2) : 100-115

Sanchez P.A. and Salinaz P. 1982. Effect of lime on exchangeable Al and corn growth. Soil Sci. 23:89-92.

Schulze, D.G., 2002. An introduction to soil mineralogy. p. 1-35. dalam J.E. Amonette, W.F. Bleam, D.G. Schulze and J.B. Dixon (eds). Soil Mineralogy with Environmental Applications. Number 7 in the Soil Science Society of America Book Series. Soil Sci. of America, Inc. Madison, Wisconsin, USA.

Sanchez, P.A. 2012. Properties and Management of Soils In the Tropics. John Wiley \& Sons, New York.

Soil Survey Staff. 2014. Keys to Soil Taxonomy. USDA Washington DC. Ames.

Sposito. 2010. The Chemistry of Soils. Oxford Univ. Press. London.

Stevenson, F.J. 2007. Humus Chemistry: genesis, composition, reactions. John Wiley \& Sons, New York.

Sufardi. 1999. Karakteristik muatan, fisikokimia, dan adsorpsi fosfat pada Ultisol bermuatan berubah akibat pemberian kompos dan pupuk fosfat. Disertasi Doktor. Program Pascasarjana Unpad, Bandung.

Sufardi. 2012. Pengantar Nutrisi Tanaman. Universitas Syiah Kuala. Bina Nanggroe. Banda Aceh.

Sufardi, Darusman, Zaitun, S Zakaria, T.F. Karmil. 2017. Soil chemical properties on dryland areas in Aceh Besar District (Indonesia). Proceeding of International Conference of Sustainable Agriculture, Yogyakarta, Indonesia.

Tan, K.H. 2005. Humic Matter in the soil and the environment.; Principles and controversies. Marcel Dekker, Inc. New York. USA.

Wada, K. 1986. Ando Soils in Japan. Kyushu Univ. Press (pbul.). Tokyo, Japan. 